\title{
THE PRACTICE OF LAW BY LAYALN AND LAY AGENCIES
}

\section{FREDERICK C. HICKS AND ELLIOTT R. KATZ†}

ADMISSION to the bar is by law restricted to natural persons of good moral character, who have passed an examination attesting to their educational qualifications and skill, and who have taken an oath to uphold the laws of the state and the honor of their profession. ${ }^{1}$ The practice of law by unlicensed persons is punishable either by fine or imprisonment, or both, either on statutory authority, ${ }^{2}$ or in the absence of a specific legislative prohibition, by reason of the court's inherent power." "Having power" to determine who shall and who shall not practice law in this state," said Mr. Justice Orr, "it necessarily follows that this court has the power to enforce its rules and decisions against offenders, even though they have never been licensed by this court." " Laymen and lay agencies cannot lawfully collect fees for performing legal services, ${ }^{5}$ and legal proceedings instituted by them may be decreed a nullity. ${ }^{*}$

* Law Librarian and Professor of Law, Yale School of Law; author of THe New Wordd ORder (1920), MTaterlals aNd ilethods of Legal ReSEARCH (1923), IIEN AND BOOKS FAMrOUS IN THE LAW (1921), and editor of High Finance in the Sixties (1929).

$\div$ Member of the Connecticut Bar; editor of the YALE LAW Jouras (1929-1930) ; and Research Assistant in the Yale School of Law.

1 Reed, Present Day Latw Schools (1928) 46. Holmgren, RuLes for ADMISSION TO THE BAR (17th ed. 1930). In some states graduates of spceified law schools are not required to take bar examinations to receire their licenses. Ibid. For recent developments in Indiana, see Lcgislature Acts on Indiana's Bar Admission Problems (1931) 17 A. B. A. Jorr. 208.

2 People v. Castleman, 294 Pac. 535 (Colo. 1930); In re Bailey, 50 IIont. 365, 146 Pac. 1101 (1915); People v. Schreiber, 250 IIl. 345, 95 N. E. 189 (1911) ("collection attorney") ; Commonwealth v. Grant, 201 MIass. 458, 37 N. E. 895 (1909); State v. Chamberlain, 132 Wash. 520, 232 Pac. 397 (1925); In re Walter Simmons, 15 Q. B. D. 348 (1885). See Note (1924) 36 A. L. R. 533.

${ }^{3}$ Re Morse, 98 Vt. 85, 126 Atl. 550 (1921).

4 People v. People's Stock Yards State Bank, 176 N. I. 901, 906 (IIl. 1931).

5 Hughes v. Dougherty, 62 Ml. App. 464 (1895). Missouri allows a recovery of three times the fee paid to an unlicensed practitioner/ Mo. REv. Stat. (1929) c. 78 \$1694.

${ }^{6}$ Stevens v. Jas. Smith Lumber Co., 54 S. D. 170, 222 N. W. 665 (1029); Gadek v. Kugler, 141 Atl. 561 (N. J. 1928); Kaplan r. Berman, 37 Mrise. Rep. 502, 75 N. Y. Supp. 1002 (Sup. Ct. 1902). 
Despite such clear prohibitions, many unlicensed individuals and organizations are today performing functions heretofore commonly regarded as within the exclusive province of the lawyer. In many instances they have been, and still are, aided and abetted by attorneys, either serving as employees or applying their skill as attorneys, to the organization and conduct of these lay agencies contrary to law. Without their aid, unlicensed law practice would probably not have developed into a serious menace to the profession. The camel having been allowed to insert its nose into the tent is now gradually evicting the present occupant. Lay agencies today actively competing with the legal profession include trust, title and insurance companies, banks, tax experts, accountants, collection agencies, notaries, and real estate brokers. The field of the attorney is further encroached upon by the activities of arbitrators, workmen's compensation boards and small claims courts. The list is constantly growing. The creation of Compensation Commissions in negligence cases, to operate somewhat like Workmen's Compensation Commissions, is being agitated. A prominent attorney has recently declared that "if the encroachments of the past twenty-five years are progressively maintained for the next twenty-five years, the chief occupation of the members of the legal profession will be that of counter clerks for corporations and like institutions." " In a recent case the commissioner's findings stated that a certain bank, through its real estate and trust departments had "transacted for its customers and others almost every form of legal business except the handling of divorce cases." 8

Some lay extremists might regard the elimination of the legal profession as not undesirable. Other laymen concede the desirnbility of maintaining a body of skilled legal practitioner's as members of a profession, but contend that the lawyer's exclusive franchise is too broad. He should be limited to those functions for .which he alone has been specially trained, such as the preparation and conduct of litigation. All other activities in which the lawyer now engages, they say, should be thrown open to laymen

i Swaffield, The Destiny of the Legal Profession (1931) 6 LOS ANGBLeg B. A. Bull. 103. See Bristol, The Passing of the Legal Profession (1913) 22 YaLe L. J. 590; Dawson, Frankenstein, Inc., (1930) 19 AMER. MercunY 274; Unlawful Practice of the T,aw, 6 Los ANGETes B. A. BuLL. 351 (1931); Johnson, Economic Changes and the Practice of Law (1931) 9 CAN. B. Rrv. 239 ; ibid. 284.

${ }^{8}$ People v. People's Stock Yards State Bank, supra note 4, at 903. A Florida Trust Company advertised "Specialists in Real Estate Litigation." Feibelman, The Passing Independence of the Bar (1931) 36 Comm. L. J. 227. In Georgia, "Legal Services, Incorporated" has just been organized to furmish attorneys and to render every kind of legal service excopt appearance in court. Lawson, The Practice of Law (1931) 36 Coms. L. J. 324. See note 35 , infra. 
and attorneys alike, letting the public decide by its patronage which should survive. Laymen, and especially corporations having skilled staffs could perform these services in connection with their regular businesses more cheaply and efficiently than they can be done by lawyers. The opposition of the bar to unauthorized law practice is regarded as merely a manifestation of defensive guild spirit, motivated by a desire to retain control of a lucrative practice. It is unfair, they contend, to grant the attorney a monopoly in the law and at the same time permit him to compete in non-professional activities.

To the above contentions, the lawyer replies that modern methods of transportation and communication, and the complex nature of modern commercial enterprises necessitate highly involved and complicated rules of conduct. The extermination of the legal profession would not accomplish the object sought by extremist laymen. There would always be needed skilled specialists, whether or not they were called lawyers. Obviously it would be better to have such specialists organized and under control so that the public might be protected from the charlatan, the unscrupulous, the ignorant and the unskilled.

Lawyers further contend that limiting their exclusive franchise to the preparation and trial of cases would inevitably destroy the legal profession. The immediate effect would be to deprive lawyers of the most lucrative part of their present practice. ${ }^{9}$ Strict economic necessity, plus the instinct of selfpreservation, would probably force many attorneys to abandon their professional ideals. The resulting cut-throat competition would deleteriously affect the administration of justice, thus defeating the aims of both laymen and lawyers. Of course, the lawyers admit, the bar has had, and still has, its shysters and undesirables, but fortunately they constitute only a small part of the profession. The growth of unauthorized law practice, and the fact that the bar is overcrowded have already resulted in an increase of professional mis-conduct. Bar Associations are doing yeoman service in getting rid of undesirables. To this end, and to complete their control over their members, they are more fully organizing themselves, in some instances by means of in-

9 The effect of unauthorized law practice is already apparent. Nearly onethird of the lawyers in North Carolina paid the minimum license tax as having incomes less than $\$ 1000$ from practice for the preceding year. 10 MLASS. L. Q. 50 (IIay 1931). A small Boston corporation advertised that it would engage the services of an attorney to look after its collection work. Nearly two hundred replies were received (including letters from graduates of high grade law schools, and men with six, eight and ten years' experience) asking for salaries from twenty-five to forty dollars. Ibid. 37 . "50\% of the lawyers in Boston do not average $\$ 3,000$ a year after their necessary office expenses are paid." Bantry, A Ncrspapcrman's Ticw of the Profession, ibid. 43, 44. 
corporation with compulsory membership, and in others, by federations of voluntary associations. Competition from without the profession is making the accomplishment of these aims more difficult, if not impossible.

Lawyers' misconduct in recent years has received wide publicity conveying the impression to the public of a degree of depravity among the members of the profession which does not exist. It should be remembered that discipline has often been administered solely for the commission of acts which were not violations of the criminal law and which if committed by laymen would not have been punishable. The imposition of this higher standard of conduct upon attorneys protects the public. The lawyer contends that, even conceding that certain specially trained laymen could ably perform some of the acts now done by lawyers, there is no guarantee that all laymen who might hold themselves out as being qualified would be capable and trustworthy. In the performance of these tasks involving trust and confidence, they are amenable only to the criminal law, in which, as defendants, they can avail themselves of constitutional and other defenses denied to lawyers in disbarment proceedings. ${ }^{10}$

Opponents of unauthorized practice of the law consider the performance of such acts by corporations as even more objectionable than when done by individual laymen. As the corporation is an artificial being, it obviously cannot satisfy the educational and character requirements for admission to the bar, nor can it take an oath and become an officer of the court subject to its discipline. As the attorney-client relationship is a purely personal one, involving mutual trust and confidence, it cannot exist between an attorney employed by a corporation and a client of the latter. The litigation would be controlled by the corporation which collected the fee. It seems inevitable that, when the interests of the corporation and the client happened to conflict, the attorney would deem his primary duty to be owing to the corporation which employed him, rather than to the client of the corporation. Whenever presented with the problem, courts have therefore held that corporations cannot practice law. ${ }^{11}$ The same

10 See 2 Thornton, AtTorneys at Law (1914) § 886 et seq.

11 Without the aid of a statute specifically directed at corporations. Matter of Co-operative Law Co., 198 N. Y. 479, 92 N. E. 15, 139 Am. St. Rep. 839, 19 Ann. Cas. 879, 32 L. R. A. (N. S.) 55 (1910); In re Eastern Idaho Loan \& Trust Co., 288 Pac. 157 (Idaho 1930); Grocers and Merchants' Bureau v. Gray, 6 Tenn. C. C. A. 87, N. Y. L. J., Dec. 6, 1915; 81 CenT. I. J. 4 (1916) ; In re Richmond Title \& Abstract Co., 2 VA. L. REG. (N. S.) 772 (1917) (Opinion of Corporation Commissioner).

Nor can a corporation practice dentistry or medicine. State v. Bailey Dental Co., 234 N. W. 260 (Iowa 1931) ; People v. Painless Parker Dentist, 275 Pac. 928 (Colo. 1929); Winslow v. Dental Examiners, 115 Kan. 450, 223 Pac. 308 (1924); Comm. v. Alba Dentist Co., 13 Pa. Dist. R. 432 
result is achieved in many states by statutes, most of which have been passed in the last few years. ${ }^{12}$ In a widely quoted case the court remarked:

"As it cannot practice law directly, it cannot indirectly by employing competent lawyers to practice for it, as that would be an evasion which the law will not tolerate. 'Quando aliquid, prohibiter ex directo, prohibitur et per obliquium.' Co-Litt. 233. - . Its [the corporation's] members might be without character, learning or standing. There would be no remedy by attachment or disbarment to protect the public from imposition or fraud, no stimulus to good conduct from the traditions of an ancient and honorable profession, and no guide except the sordid purpose to earn money for stockholders." 13

Nor could a corporation legally practice law even if all the shares were owned by lawyers and it engaged only lawyers to perform legal services. ${ }^{14}$ The danger arises from the fact that if the shares were descendible by inheritance or purchaseable or capable of being hypothecated it might not be long before the corporation would be controlled by laymen interested solely in the making of money and not concerned with the administration of justice or the attainment of professional honor..15 The client's

(1897); Atty. Gen. v. George C. Smith Co., Ltd., [1909] 2 Ch. 524; People v. Woodbury Derm. Institute, 192 N. Y. 454, 85 N. E. 697 (1908) (hospitals employing licensed doctors excepted). Cf. State v. Electro-Mredical Institute, $74 \mathrm{Neb} .40,103$ N. W. 1078 (1905).

122 Ark. Laws 1929, Act 182; ILr. Rev. STAx. (Smith-Hurd, 1929) c. 32 §§ 411-415; LA. Rev. STAT. ANN. (MTarr. Supp. 1926) 55-56; IID. ANN. CODE (Bagby, 1924) Art. 27 § 19; MLASS. GEN. LAwS (1921) c. 221 §§ 46-47; MICH. Comp. Laws (1929) c. 197 \& 10175; Minn. Laws 1931 c. 114; 1 Io. REv. Stat. (1929) c. 78 §§ 11692-11693; N. J. Codip. STAT. (Supp. 1924) $\S \S 52-214$ p-r, (Supp. 1930) 52-214t; N. Y. CoNs. Laws (Cahill 1930) c. $41 \S \S 280,271$ a; N. C. Public Laws 1931, c. 157 §§ 1, 2; 2 OrE. Code AwN. (1930) $\S \S 32-504$ to $32-506,22-1213$; R. I. GeN. LAWs (1923) c. 401, § 6238; Utah Laws 1927, c. 78 \$ 345; 2 WASH. CoNrP. STAT. (Remington, 1922) § 3231 (9) (applies to trust companies only); WEST VA. CODE (1931) c. 80 , art. $2, \S 5$.

Several states merely forbid incorporation for professional services. Idaho Sess. Laws 1929, c. 262, § 2; OHIO GEN. Code (Page, Supp. 1930) § 8623-3. See HAWAII REv. LAWS (1925) § 3331 (Joint Stock Companies), 2 S. D. CoMP. LAWS (1929) $\$ 8758$.

${ }^{13}$ Matter of Co-operative Law Co., supra note 11 at 483,92 N. E. at 16.

14 Matter of Associated Lawyers' Co., 134 App. Div. 350, 119 N. Y. Supp. 77 (1909) (all but five of the shareholders were lawyers); see State $v$. Merchants Protective Coop., 105 Wash. 12, 177 Pac. 694 (1919).

It has been reported that KaN. Rev. Stat. ANN. (1923) c. 17, 204 and NEB. CoMp. STAT. (1929) c. $24 \$ 901$, permit incorporation by lawyers for the practice of law. Note (1931) 44 HARv. L. REv. 1114, n. 2, n. 15. These statutes merely permit members of the learned professions to incorporate into non-profit associations, e. g., bar associations.

${ }_{15}$ State v. Merchants Protective Corp., supra note 14, at 17, 177 Pac. at 696. 
intimate social and business affairs would no longer be protected by the attorney-client privilege, but would be exposed to the prying eyes of inquisitive shareholders. ${ }^{16}$

\section{II}

Undoubtedly lay practice of the law by individuals and corporntions is forbidden. Nevertheless, the problem remains of determining what constitutes practice of the law, because laymen constantly maintain that acts performed by them do not come within the prohibition. When confronted with this question, courts have usually had to deal with inadequate statutory definitions merely forbidding laymen to act as attorneys, or to hold themselves out as such. ${ }^{17}$ Therefore, on account of the frequent recurrence of the problem in recent years, many states have passed fuller and more elaborate definitions. ${ }^{18}$ Missouri, for example, going further than most states, has distinguished between "law practice," and "law business" (office practice), both of which, however, are forbidden to laymen and lay agencies.

"The 'practice of the law' is hereby defined to be and is the appearance as an advocate in a representative capacity or the drawing of papers, pleadings or documents or the performance of any act in such capacity in connection with proceedings pending or prospective before any court of record, commissioner, referee or any body, board, committee or commission constituted by law as having authority to settle controversies. The "law business' is hereby defined to be and is the advising or counselling for a valuable consideration of any person, firm, associntion or corporation as to any secular law or the drawing or the procuring of or assisting in the drawing for a valuable consideration of any paper, document or instrument affecting or relating to secular rights or the doing of any act for a valuable consideration in a representative capacity, obtaining or tending to obtain or securing or tending to secure for any person, firm, association or corporation any property or property rights whatsoever." 10

Despite this recent legislative activity, the actual status of lay practice is not clear. No sharp picture of it can be presented. The best that can be done is to describe and comment upon

${ }^{16}$ Shareholders have the right to examine the books of the corporation. BaLlantine, Manual of Corporation Law (2d ed., 1930) 545.

${ }^{17}$ Cal. Code CIv. Proc. (Deering 1923) § 1209 sub. \$ 13; 1 Colo. ANN. Stat. (Courtright's Mills, 1930) 130; IDAHo SESS. Laws 1925, c. 89, $\$ 6$; Tenn. ANN. Code (Shannon, 1918) § 5772; 2 Conn. Gen. Stat. (1930) $\S 5345$; VA. CODE (1930) § 3408.

${ }^{18}$ ALA. CoDe (1928) § 6248; 2 Miss. CODE ANN. (1930) § 3710; MINN., ORE., and Mo. supra note 12.

10 Mo. loc. cit. supra note 12. 
typical situations, such as those which follow, and to tell how courts have dealt with them.

Appearances Before Judicial Bodies While anyone who has attained his majority can personally appear in court to protect his own interests, ${ }^{20}$ it is equally well settled that no one can conduct litigation or represent another in court unless he is a licensed attorney. ${ }^{21}$ This ban is not limited to actual appearances in court but includes the preparation of writs, pleadings,, 2 and appeal briefs. ${ }^{23}$

But the matter of appearances in a representative capacity before administrative or quasi-judicial bodies presents a rather awkward problem. Laymen are allowed to practice before Federal administrative bodies provided they have secured formal permission from the particular body before which they are to appear. ${ }^{24}$ The Association of Practitioners before the Interstate Commerce Commission has virtually established a "bar" of its own including registered laymen as well as licensed attorneys. At a recent meeting of this group an elaborate code of ethics was adopted and a committee was appointed to formulate standards of education. ${ }^{25}$ In view of the highly specialized nature of the

201 Thornton, Attorneys at LeAw, (1914) 27. Cf. Copeland v. Dabbs, 129 So. 88 (Ala. 1930) (can prepare own conveyances).

${ }^{21}$ An unlicensed person cannot represent another in court as agent or attorney in fact. THORNTON, op. cit. supra note 20 , at 28 . A statute permitting such representation if authorized by the "client" in writing vas declared unconstitutional. MIcKoan v. Devries, 3 Barb. (N. Y.) 196 (1848). It has been held that a corporation cannot be represented in court except by a licensed attorney. N. J. Photo Engraving Co. v. Carl Schonert \& Sons, 95 N. J. Eq. 12, 122 Atl. 307 (1923); Black \& White Operating Co. v. Grosbart, 151 Atl. 630 (N. J. Ct. of Err. \& App., 1930). Nor can a disbarred attorney, even if he is a sole shareholder, represent a corporation. Cary \& Co. v. Satterlee \& Co., 166 IIinn. 507, 208 N. W. 408 (1926).

${ }^{22}$ See Chautauque County Bank v. Risley, 6 Hill 375 (N. Y. 1844).

23 Ellis v. Bingham County, 7 Idaho 86, 60 Pac. 79 (1900). Duyster v. Crawford, 69 N. J. L. 229, 54 Atl. 823 (1903). See Fallon v. State, 69 S. E. 592 (Ga. App. 1910). Cf. Johnson v. Davidson, 54 Cal. App. 251, 202 Pac. 159 (1921), and criticism in Note (1922) 10 CALIF. L. REv. 146.

24 See In re Gibbs, 278 Pac. 371 (Ariz. 1929); MIulligan v. Smith, 32 Colo. 404, 76 Pac. 1063 (1904) (land office).

"An attorney cannot properly be associated with or employed by a layman who is admitted to practice in the Patent Office, when that layman does business under the name of a firm which represents itself to be "attorneys' and 'solicitors in patent causes." Opinion 32, A. B. A. Comm. on Professional Ethics and Grievances, (1931) 17 A. B. A. Jour. 468. A layman was punished in contempt proceedings for holding himself out as an attorney by inserting the following in a city directory: "- Attorney, Solicitor of American \& Foreign Patents." People v. Erbaugh, 42 Colo. 480, 94 Pac. 349 (1908).

25 I Reports of Association of Practitioners before the I. C. C., 261 (1930). See Rules Governing the Recognition of Amtornexs, Agents, 
work, if the association succeeds in its objects, the public interests would seem to be just as well served as if their membership had been restricted to duly licensed attorneys.

In the states, no organizations of lay practitioners have been set up, and there are only a few decisions on the subject. Under the New York Tax Law, laymen having "knowledge of the facts" are permitted to make applications to the tax board, in behalf of third parties, for the reduction of assessments. ${ }^{20}$ Enrlier cases in the First Department of the Appellate Division denied to corporations the privilege of filing such applications on the ground that being artificial persons, they could not have "knowledge of the facts." ${ }^{27}$ A later decision limited the earlier cases to those instances where a writ of certiorari was taken to review the assessment.28 But New York corporations offering to furnish legal services in condemnation proceedings have been held to be illegally practising law.29 Some of the newer statutes, attempting fuller definitions of the practice of law, specifically forbid laymen to appear in a representative capacity before administrative bodies and officials. ${ }^{30}$

Of course a corporation can employ attorneys in and about its own immediate affairs, or in litigation to which it may be a party. But at times the corporation employs attorneys to inct both for itself and its customers. Trust companies employ at-

and other Persons to Represent Claimants before the Bureau of PenSIONS (1930).

${ }^{26}$ N. Y. Cons. Laws (Cahill, 1930) c. 61, § 37. Cf. Dunlap v. Labus, 112 Ky. 237, 65 S. W. 441 (1901) (layman can negotiate with tax commissionor for a reduction in the taxes of a third party).

${ }^{27}$ People ex rel. Trojan Realty Corp. v. Purdy, 174 App. Div. 702, 162 N. Y. Supp. 56 (1916); People ex rel Floersheimer v. Purdy, 174 App. Div. 694,162 N. Y. Supp. 70 (1916), rev'd on other grounds, 221 N. Y. 481, 116 N. E. 390 (1917) ; People ex rel. Holzman v. Purdy, N. Y. L. J., Fob. 25, 1916.

${ }^{28}$ Tanenbaum v. Higgins, 190 App. Div. 861, 180 N. X. Supp. 738 (1920). The preparation of an appeal from the Fire Department to the Board of Standards and Appeals, has been held not to constitute practice of tho law. Croker Nat'l Fire Prevention Co. v. Harlem etc. Works, 132 Misc. Rep. 687, 230 N. Y. Supp. 670 (Mun. Ct. 1927). Cf. Articles in N. Y. Times, May 7-31, June 1-1'4, Aug. 5-22, Sept. 10-17 (1930), Mar. 5, Jl. 13-31 (1031) on practice before the $\mathrm{N}$. Y. Bureau of Standards and Appeals by Wm. F. Doyle. The appearance before the legislature to secure a pardon has boen held not to constitute practice of law. Bird v. Breedlove, $24 \mathrm{Gn} .623$ (1858).

${ }^{29}$ Even though they hired attorneys to represent the owners. U. S. Titlo Guaranty Co. v. Brown, 166 App. Div. 688, 152 N. Y. Supp. 470 (1016), aff'd., 217 N. Y. 628, 111 N. E. 828 (1916); see Matter of City of Now York (Avenue A), 144 App. Div. 107, 128 N. Y. Supp. 999 (1911), aff'd., 204 N. Y. 625, 97 N. E. 1103 (1912); Matter of Bensel, 68 Misc. Rop. 70, 124 N. Y. Supp. 726 (Sup. Ct. N. Y., 1910), aff'd 139 App. Div. 022, 124 N. Y. Supp. 110 (1910).

30 AIA. CODE (1928) § 6248; Mo., loc. cit. supra note 12. 
torneys in probate proceedings; banks and title, and mortgage companies employ attorneys in foreclosures. In some instances, attorneys are employed on yearly retainers, and all sums allowed by the court as attorneys' fees are turned over to the corporation. A bank utilizing this scheme has been recently held to be practicing law. ${ }^{3 I}$ The attorney so employed may be subjected to disciplinary action. ${ }^{32}$ Two of the more recent statutes specifically deal with the matter. One provides that attorneys' fees cannot be exacted in foreclosure proceedings unless an attorney who gets the entire fee, without sharing it, and without rebates of any kind, is actually employed..$^{33}$ The other, in addition to this provision, makes it unlawful for a corporate administrator, executor, trustee, or guardian to do legal work in probate or other court proceedings unless through a licensed attorney maintaining his own place of business and not an officer or employee of the corporation. Further, that no attorneys' fees are to be charged unless actually paid to the attorney without sharing or rebates. ${ }^{3 *}$

Drafting Legal Instruments-Conveyancing and Title Companies It is obvious that the practice of law is not limited to the conduct of cases in court. ${ }^{35}$ To-day a large part of the work of

31 People v. People's Stock Yards State Bank, supra note 4.

32 In re Otterness, 232 N. W. 318 (Minn. 1930).

33 N. C. Public Laws, 1931, c. 157, § 3.

34 MINN. LAWS 1931, c. 114 .

The Minnesota court had previously intimated that corporations could retain attorney's fees in foreclosure proceedings provided that they do not exceed the amount actually paid to the attorney as salary or result in any profit to his employers. In re Otterness, supra note 32. Cf. Report of Committee on Uniawful Practice of the Law, 12 N. Y. Countr L. A. Year Book, (1920) 155, 177. Cf. Compromise Agreement in Ohio, \$§ 6, 7, zinfra note 113.

${ }^{35}$ "It is too obvious for discussion that the practice of law is not limited to the conduct of cases in court. According to the generally understood definition of the practice of law in this country, it embraces the preparation of pleadings and other papers incident to actions and proceedings on behalf of clients before judges and courts and in addition conveyancing, the preparation of legal instruments of all kinds, and, in general, all advice to clients and all action taken for them in matters connected with the law. An attorney at law is one who engages in any of these branches of the praetice of law. The following is the concise definition given by the Supreme Court of the United States: 'Persons Acting professionally in legal formalities, negotiations, or proceedings by the warrant or authority of their clients may be regarded as attorneys at law within the meaning of that designation as used in this country." " [Savings Bank v. Ward, 100 U. S. 195, 199, 25 L. Ed. 621, 623 (1879)]. In re Duncan, 83 S. C. $186,189,65$ S. E. $210,211,24$ L. R. A. (N. S.) 750, 753, 18 Ann. Cas. 657, 658 (1909) (italics ours).

The only statement to the contrary is a dictum in Atlanta Title \& Trust Co. v. Boykin, 157 S. E. 455 (Ga. 1931) that the practice of law is limited to appearances in court on the ground that most of the Georgia statutes on the subject had used the phrase "practice law in the courts." A more 
the lawyer is performed in the office. The character of this work requires that it be performed by trained persons who may ersily be held to account by the courts.

“... Very little can go wrong in a court where the proceedings are public and the presiding officer is generally a man of judg" ment and experience. Any judge of much active work on the bench has had frequent occasion to guide the young practitioner or to protect the client from the haste or folly of an older one. Not so in the office. Here the client is with his attorney alone, without the impartial supervision of a judge. Ignorance and stupidity may here create damage which courts of the land cannot thereafter undo." 36

This necessity for trained individuals readily amenable to discipline is a forcible argument for prohibiting laymen from engaging in "office practice."

The drafting of legal instruments is one of the important phases of such practice. In simple conveyances this work has become somewhat stereotyped and is often performed merely by filling out printed blanks. Because of this apparent simplicity it has been contended that conveyancing is a proper prerogative of laymen and title companies. While this argument is supportable in the case of simple conveyances, if there is a slight deviation from the normal set-up, the use of such forms may have disastrous consequences. Legal training is required to determine whether the set forms are applicable, and if not, to prepare more specialized instruments. It is futile to argue that conveyancing in England was at one time the function not of attorneys but of scriveners, since the latter, although not attorneys, were licensed practitioners subject to definite rules and regulations. ${ }^{37}$ The same is true of the present-day foreign notary. While the matter cannot yet be regarded as definitely settled in this country, it seems to be fairly well established that neither individual laymen nor title companies can engage in conveyancing as a business."

comprehensive statute is now being prepared. See What is "Tho Pruotion of Law" in the State of Georgia (1931) 2 GA. LAWYER 251. The last statuto cited by the court that used this phrase was passed in 1847. Since then tho more general phrase "practice of law in the state" has been used. Tho opposite result has been reached in cases where the last statuta on tho subject had merely forbidden unlicensed persons "to practice law in tho courts." Grocers \& Merchants' Bureau v. Gray, supra note 11; In ro Duncan, supra; In re Bailey, supra note 2; see, People v. Schroiber, supra note 2.

${ }^{36}$ People v. Alfani, 227 N. Y. 334, 339, 125 N. E. 671, 673 (1910).

37 Christian, A SHORT History of Solicitors (1896) 141-144. For those permitted to draft legal instruments in England, see 2 HaLsdurx, LAW OF ENGLAND (1908) §363 (§638, advising).

${ }^{38}$ People v. Alfani, supra note 36 . People v. Title Guaranty and Trust Co., 227 N. Y. 366,125 N. E. 666 (1919) (bill of sale of personalty). For 
Whether or not title companies, as an incident to their business, can draw legal papers is not so clear.

Title companies perform a necessary and useful function in searching and insuring titles. Often they act also as conveyancers, through a representative, who may or may not be a lawyer. If, as is not uncommon, the parties do not employ counsel, the draftsman is placed in the anomalous position of representing three parties all of whose interests may be mutually adverse. The title insurance contract must contain all the exceptions necessary to protect the insurer; the buyer, ignorant of legal terminology, should be advised of any restrictions, covenants or encumbrances which might affect the marketability or use of his property; and the seller should be fully apprised of everything which he has covenanted to do.39 One court has therefore refused to permit title companies to do any conveyancing whatsoever. "The argument that unless they are to be permitted to draw deeds and convey titles, they will have none to insure, is as specious as would be an argument that a fire insurance company should be allowed to make contracts to build houses in order to insure them." ${ }^{10}$ In three states it is apparently permissible for title companies to draft conveyances in those instances in which they have either searched or insured the title. But in only one can they make a business of drafting legal instruments, or hold themselves out as qualified to do so.42

an example of the disastrous consequences which may result from conveyancing by laymen, see Cohen, Lay Practice of the Law Injures Clicnts, not the Legal Profession (Aug. 1921) 5 AMr. Jud. Soc. Jour. 52.

${ }^{39}$ Report of Committee on Unlawful Practice of the Law, 13 N. T. COUNTY L. A. YEAR BOOK (1921) 169, 176.

For example, in one instance, when a title company prepared a deed, it contained provisions that the premises were conveyed subject to building restrictions and regulations adopted by the city authorities (a matter subject to frequent litigation); and that the purchase-money mortgage should contain a clause subordinating the same to the first mortgage on the premises or to any new mortgage which might be raised to take the place of the first mortgage. None of these matters had been discussed. The vendor's oral promise to bear the assessment for a street which was to be opened through the property was not included in the deed. There was also included: "The seller shall give and the purchaser shall accept a title such as the-Company will approve and insure." The validity of this clause has also been frequently litigated. Whether or not these provisions were unjust or improper, it would seem that both vendor and purchaser might have profited by independent legal advice. See dissent, People v. Title Guaranty and Trust Co., 191 App. Div. 165, 167, 181 N. Y. Supp. 52, 53 (1929).

${ }^{40}$ Gauler v. Solicitors' Loan and Trust Co., 9 Pa. C. C. R. 634, 635 (1891).

41 N. Y. Penal Law 271-a; N. J. Conip. Stat. (Supp. 1930) 52-214 t. The latter statute also permits real estate brokers and money lenders to da. such conveyancing as is incidental to their business. In Georgia, title com- 
Neither laymen nor lay agencies can draft for third parties wills, ${ }^{42}$ contracts and similar agreements securing legal rights. ${ }^{43}$ As expressed by one court:

"... Where an instrument is to be shaped from a mass of facts and conditions, the legal effect of which must be carefully determined by a mind trained in the existing laws in order to insure a specific result and guard against others, more than the knowledge of the layman is required." ${ }^{44}$

The organization of corporations, and the drafting of the necessary papers has also been considered to be practice of law even though such work has apparently become so simplified that laymen can fill out the forms "sometimes without untoward consequences." Statutes must be construed, the corporation must be so organized that it may best meet the needs of the projector's, and all proper papers must be drawn." "All this calls for tho

panies can apparently do all conveyancing. Atlanta Title and Trust Co. v. Boykin, supra note 35 . Several of the other statutes forbidding corporato practice of law provide that the statutes shall not apply to corporntions lawfully engaged in the examination and insuring of titles to real proporty. ARK.; LA., MASS., MrCH., R. I., WEST VA., loc. cit. supra note 12 . Theso statutes are not intended to permit such corporations to practice law. They merely permit the examination and insuring of titles. Whother or not the company will be permitted to do conveyancing in those instancos in which it insures the title would seem to depend upon whether tho court regards such conveyancing as being a necessary incident to the company's "legitimate business." See People v. Title Guaranty \& Trust Co., oupra note 38. (the conviction was reversed on the ground that the caso morely established an isolated act). Report of Committee on Unlawful Practioc, 12 N. Y. County L. A. Yaar BooK (1920) 155, 168; cf. People v. Titlo Guaranty and Trust Co., 230 N. Y. 578, 130 N. E. 901 (1920).

In one state title companies can make abstracts or certifications of titlo only when they act through licensed attorneys, or their principal offlcory, 2 MXSS. CODE ANN. (1930) \&3710.

42 In re Eastern Idaho Loan \& Trust Co., supra note 11. People v. Peoples Trust Co., 180 App. Div. 494, 167 N. Y. Supp. 767 (1917).

By statute expressly: 2 Miss. CODE ANN. (1930) \$ 3710; and MINN, N. C., N. J., ORE. (Trust Cos.), WASH. (Trust Cos.), all loo. cit. supr't note 12. Other statutes merely prohibit the drafting of "legal instruments." 2 Miss. CoDE ANN. (1930) § 3710.

43 Eley v. Miller, 7 Ind. App. 529, 34 N. E. 836 (1893) ; of. Barr. v. Cardell, 173 Iowa 18,155 N. W. 312 (1915).

44 In re Eastern Idaho Trust Co., supra note 11, at 159.

45 Matter of Pace, 170 App. Div. 818, 156 N. Y. Supp. 641 (1915), Noto (1916) 82 Cent. L. J. 61; N. C. Public LAws, 1931. c. $157 \S \S 1$, 2. Seo Opinion 31, Committee on Professional Ethics and Grievances, 17 A. B. A. Jour. 468 (1931). A few statutes specifically permit corporations and others to furnish attorneys with information and clerical services concer'ning incorporation, providing "the lawyer receiving the information shall maintain full, professional and direct responsibility to his clients for the information and services so received." MINN., ILL., ARK., LA, loo. cit. supra note 12. 
application of legal knowledge and skill and the consequent rendering of legal advice and services." 16

Wills and Trust Companies Only members of the bar are permitted to draft wills. ${ }^{47}$ To be properly qualified to advise a testator, learning is required in such complicated fields of the law as perpetuities, trusts, and legal and equitable estates. It is also of the utmost importance that the testator should be able to impart confidential communications regarding his family relationships to one who is under a duty to respect that confidence. ${ }^{43}$ But service as administrators and executors is not considered to be practice of law, and trust companies often act in those fiduciary capacities. The number of such companies has increased by leaps and bounds until to-day there exists a vast competitive struggle for corporate fiduciary work. Billboards, newspapers, magazines, electric signs, radios and other moderm advertising media are constantly informing the public of the readiness of the trust company to act in the rôles of executor and trustee.

As an added inducement to the thrifty, many trust companies offer to draft wills "free of charge" provided the company is named in the instrument as executor or trustee. Others have a regular schedule of fees for this service. Since corporations cannot practice law, the drafting of such instruments by ernployees of the trust company is illegal::0 This is true also when the will is drawn by an attorney who is connected with the regularly retained firm of legal advisers of the company.51

The twenty-seventh canon of professional ethics adopted by the American Bar Association forbids advertising for, and the solicitation of, legal business.

". . It is equally unprofessional to procure business by indirection through touters of any kind, whether allied real estate firms or trust companies advertising to secure the drawing of wills or offering retainers influenced by the lawyer. ..." 52

\footnotetext{
36 MIatter of Pace, supra note 45, at 826, 156 N. Y. Supp. at 646.

47 Supra note 42.

${ }^{48}$ See People v. Peoples Trust Co., supra note 42, at 497, 167 N. Y. Supp. at 769 .

An ex-notary, and ex-bank cashier tells of the disastrous consequences and years of litigation resulting from the fact that he had drafted a will improperly. Jones, How I Drew Old Tom Lather's IFill, (1920) 91 CENT. L. J. 118.

49 Metcalfe v. Bradshaw, 145 Ill. 124, 33 N. E. 1116 (1893).

so Supra note 42.

51 People v. Peoples Trust Co., supra note 42 (no charge had been made either by the corporation or the attorney for services in advising, drafting and supervising the execution of the instrument).

52 See also Canon 28.
} 
Obviously a lawyer would be disciplined if he secured clients by advertising his skill in probate matters and in the drawing of deeds and trust agreements. The same result would follow if he secured this business by means of solicitors, runners, or salesmen. Likewise, he would be violating this canon were he to advertise that he would charge no fees for drawing wills if he were named as executor or trustee. He ought not to be allowed to escape discipline when the solicitation is done by a corporation. It is immaterial that he receives his compensation in the form of a salary rather than as fees paid directly by the client.

"A man cannot serve two masters" and serve both of them well. Courts have always been extremely watchful to detect the slightest possibility of an adverse interest in those people who help the testator execute his will. This is clearly demonstrated by the fact that one who merely performs the ministerial act of signing his name to a will as a witness is not permitted to receive any bequests under the will. ${ }^{54}$ It would seem to follow, a fortiori, that the person under whose advice and guidance the will is made should be required to be completely disinterested.

It is obvious that the salaried employee of the trust company cannot be completely disinterested. At times the best interests of the testator are served by an outright disposition of his estate, but then there are no trustee's fees. Circumstances might make it desirable that there be two trustees, but in that event the company would have to share the fees with another. It is often in the client's interest that the trust be of short duration, but those which endure over a long period of years are most profitable to the fiduciary. The client's interest might demand that the powers of the trustee be rather limited, but the company wants them as broad as possible. It is in the interest of the trust company that a provision be inserted making it liable only for actual misfeasance or gross negligence, while the client's interest might demand that the trustee be held to a high degree of care.

The trust officer is thus placed in an awkward position. His salary is directly or indirectly dependent upon the amount of

\footnotetext{
${ }^{53}$ Lawyers, whether officers of the company or not, who tako part in such advertisement or solicitation; or who give legal advice in connection with wills and trust instruments to patrons who have been secured by such solicitation; or who take part in the preparation of such instruments for patrons secured by such solicitation are violating canon 27. Letter from Howe, Chm'n. of Committee of Professional Ethics (A. B. A.) printed in McCullen, infra note 55. Crosby, The Unlawful Practica of The Law (1929) 2 CaI B. Proceedings 124. See also Opinion VIII of this committee, 50 A. B. A. Rep. 518 (1925); and Opinion X, 52 ibid. 357 (1027); Note (1914) 79 CENT. L. J. 111; Joint Statement of Bar Associations, N. Y. L. J., May 12, 1931.

54 PAGE, Wills (2d ed., 1926) § 303 et seq.
} 
trust business which he secures. As a conscientious employee he will try to further its interests whenever possible. It is a rather unusual man who under such circumstances solely considers the interests of the testator. And even such conscientious men, trained in the trust company atmosphere and possibly having exaggerated ideas of the advantages of trusts and corporate fiduciaries, might easily convince themselves that the interests of the client and of the company were identical.

In some companies, the trust officer advises the prospective testator and then drafts the will himself. In others, the will is drawn by a member of the company's staff of attorneys. Sometimes, the testator is advised to consult his own attorney. Often this advice, given in an off-hand manner while the details of the testament are being considered, is overlooked. Continued praise of the company's capabilities, and references to the fact that advice is given free of charge, make recourse to an attorney seem unnecessary. If he is consulted, the attorney is often forced to approve the company's suggestions "or appear as a mere carping critic," since "the testator's mind and thoughts have been so filled with the company specialist's views, and he has been so thoroughly and completely moulded to the company's opinion of what is best for him, that he has not much patience with the views of anyone else." 5

The main advantage urged in favor of the corporate trustee is its permanency.58 The recent failures of institutions whose position in the banking world formerly seemed as firm as the rock of Gibraltar, have served to lessen the force of this argument. ${ }^{57}$ It is also true that the welfare of an estate is often best promoted by joining an individual as co-trustee with the company. ${ }^{58}$ This individual would normally be the testator's counsel, a member of his family, or a business associate, with provision made for succession by another individual in the event of death.

The individual co-trustee may not only serve as a check on investment by the company in securities in which it is directly

${ }_{55} \mathrm{McCullen}$, Report to Bar Ass'n. of St. Louis Conccrning Banlss and Trust Companies, (Feb. 24, 1929) 18; See Report of Eacc. Comm. of B.A. of St. Louis on Unauthorized Practice of Lau, ctc. (Jan. 13, 1980); Jackson, Competition and Cooperation Betwcen Bar and Corporate Fiducinrics, (1931) 17 A. B. A. Jour. 656.

${ }^{56}$ Although trust companies are generally well managed, it is also true that some are mismanaged. See Letter from a Trust Officer, 48 Trust Cos. 621,622 (1929).

5: There were over 1,000 banking suspensions during 1930, and over 6000 during the last decade. "One bank in five has closed its doors since 1920." Stephenson, High Mortality in Banking and the Remedy, (1930) 51 Trust Cos. 739.

58 The argument has also been advanced that the position of executor can best be filled by an individual. The period of executorship is compara- 
interested but may also maintain an active personal interest in the beneficiaries scarcely possible for a corporation and certainly not to be expected. The layman is prone to believe that his affairs will receive the personal attention of certain high officials in the company, whose abilities and business acumen he respects. The greater the amount of business entrusted to. the firm the more likely it is that estates will receive mere routine though careful attention, which at its best is probably no better than that which could be given by a competent individual trustee. The lawyer who has been advising the testator during his lifetime would seem to be the logical person to help administer the estate after his decease. ${ }^{59}$ The likelihood of such a desirable arrangement is at least increased, and the possibilities of corporate abuses correspondingly diminished, when an independent attorney is engaged to draft the will.

Mercantile and "Protective Associations," Collection Agencies Trade associations have performed many beneficial services in raising the standards of their respective industries and in advancing the interests of the group through coöperative efforts. There has, however, been a marked tendency in some of these associations to depart from their legitimate functions and to attempt to practice law by means of their legal or collection departments. For example, an apartment house owner's association employed a staff of attorneys and offered its members the following services:

"Eviction of tenants at no legal expense; Legal Advice free to members; Collections out of Court at no expense to members; Collection through court-cost only one-fourth of amount collected; other legal services at no expense to members."

Despite the defense offered by the association that it was a nonprofit organization, an injunction was issued forbidding the further rendition of these services. ${ }^{00}$

Some automobile owners' associations offer the services of their legal department gratis to members to defend them in specified minor courts and to advise them generally as to the applicability of new legislation to the activities of motorists. Merely giving advice to members as to their legal rights in civil matters has been declared to be unlawful. In the same case, an association

tively brief and losses occasioned by dishonest executors are inconsiderable. Report of Comm. on Scope and Practice of the Law, 53 N. Y. S. B. A. REP. (1930) 432.

59 1bid; Pugh, Strengthening the System of Personal Fiduciaries, (1031) 17 A. B. A. Jour. 575.

${ }^{\circ 0}$ Dworken v. Apt. House Owners Ass'n., 38 Ohio App. 265, 3 Ohio Bar Rep. 627 (1931). 
which adjusted for its members claims arising from automobile accidents, by negotiating with the opposite parties or their counsel, was held to be illegally practicing law, even in the absence of actual litigation. ${ }^{61}$

Some of the so-called trade or protective associations perform no legitimate functions whatsoever. They are either organizations incorporated by laymen to practice law for the benefit of their shareholders, or are organized by lawyers to solicit business for them. A few associations were openly organized for the practice of law. The charter of one included the purpose "to operate an office or offices for the general practice of law in all its branches, to advise, assist and render all legitimate services in all sorts of legal business."

The following method of organization is typical of many of these so-called protective associations. A certain firm was incorporated "to collect debts due its members or clients, to employ attorneys for said members or clients and to pay for such legal services for and on behalf of its said members or clients." Legal advice and consultation on business matters were furnished gratis to members at the offices of the association's attorneys. Legal papers, such as notes, mortgages, deeds and wills, were drawn without charge except for the stenographers' fees. Members were represented in civil and criminal actions in police and justice courts within a certain locality. In quo warranto proceedings the firm was held to be illegally practicing law and fined one thousand dollars. ${ }^{.3}$

Another type of "protective association," offering the services just enumerated, utilizes the following scheme. It engages an attorney or firm of attorneys, and then solicits "memberships" at an annual fee, for example, ten dollars. The corporation retains nine dollars and gives one dollar to the attorneys. One such association, when charged with illegally practicing law, contended that its sole function was to bring business men and

61 Dworken v. Cleveland Automobile Club, 3 Ohio Bar Rep. 646 (c. p. 1931); Goodman v. Cincinnati Automobile Club, 4 Ohio Bar Rep. 257 (c. p. 1931).

The following letter appears in 2 Cons. MTOTORIsT 8 (July 1931). "Gentlemen:

I take the occasion to thank the A.A.A. and to tell its members of the efficient and valuable service rendered to me by MIr. - , attorney for the A.A.A., in collecting damages for injury to my car. MIr. secured a complete and prompt settlement and sent me a chcels for the same... (italics ours).

(signed)___ _

62 Creditors National Clearing House v. Bannwart, 227 Miass. 579, 116 N. E. 886, 887, Ann. Cas. 1918 C, 130 (1917).

63 People v. California Protective Corp., 244 Pac. 1089 (Cal. App. 1926). The attorneys participating are violating the ethical rules against solicitation. In re Gill, 104 Wash. 160, 176 Pac. 11 (1918). 
attorneys together, since everything except the collection of membership fees was done by the attorneys. The court held that if the corporation was not actually performing the services offered, it was illegally soliciting business for attorneys, and if it was doing what it promised to do, it was illegally practicing law. ${ }^{64}$

Since the extension of credit is an important phase of modern merchandising, an effective method of enforcing the payment of bad claims is essential. At first, practically all of this work was done by attorneys. But lay agencies have been so successful, and have multiplied so rapidly, that they have taken over a large proportion of the collection business. ${ }^{65}$ Is this growth to be taken as an indication that lay agencies are more efficient than lawyers, or are we to attribute it to the fact that lawyers have been hampered by the code of professional ethics forbidding the solicitation of business?

The dictum of one court was that the collection of claims without suit constitutes practice of law and is therefore forbidden to lay agencies. It argued that when it is considered that the agency is:

“. . . generally entrusted with the evidences of debt, with transcripts from its clients' private books, with access to its correspondence, and further, that the statement of the case made by the client involves disclosures which ought to be privileged; when it is considered that the dunning letter is ordinarily preliminary to a suit carried on by disguised attorneys acting as the employee of the corporation; and finally, when it is realized that the money collected belongs to the client and ought to be subject to court orders in summary proceedings, there is good denl to be said in favor of holding that the operation of a collection agency, with or without legal proceedings, constitutes the practice of law." ${ }^{\circ}$

A contrary view in the same state had been taken in an earlier dictum. ${ }^{67}$ On several occasions, collection agencies have been held

04 State v. Merchants Protective Ass'n., supra note 14. People v. Morchants Protective Corp., 189 Cal. 531, 209 Pac. 363 (1922).

65 Unauthorized Practice, 1 GA. LAWXER 64 (1930).

${ }^{60}$ See Meisel v. Nat'l. Jewelers Board of Trade, 90 Misc. Rep. 19, 28 (N. Y. 1915) ; Hittson v. Browne, 3 Colo. 304 (1877) ; of. Moore v. Staser, 6 Ind. App. 364, 32 N. E. 563 (1892). One court has forbidden the sonding of dunning letters by laymen with threats of adopting judicial proccedings if the debts are not paid. Toledo Bar Ass'n v. Merchants' Credit and Adjustment Co., 4 Ohio Bar Rep. 239 (1931). The same result has beon reached in Quebec by statute. Le Barreau de Montreal v. Sprague's Morcantile Agency, 25 Quebec Cour Superieure 383 (1904) (61 Vict. (Q.) ch. 27 amend., § 3562 a. S. R. Q.).

67 Matter of Associated Lawyers, supra note 14, at 353. 
to be illegally practicing law. But as in almost all these cases additional factors were present such as the fact that the agency offered to furnish legal advice, ${ }^{\text {ss }}$ or to draft legal instruments, ${ }^{\text {c3 }}$ or to institute legal proceedings when necessary, ${ }^{70}$ or to represent "members" in certain inferior courts," these decisions would not necessarily prohibit the collection of claims by lay agencies without suit. But the presentation of proofs of claim in bankruptcy process, ${ }^{72}$ and the preparation of assignments for the benefit of creditors ${ }^{\mathrm{i}}$ have been both forbidden to collection agencies.

One of the serious abuses by such agencies is the solicitation of claims with which to force a debtor into involuntary bankruptcy. By this means they often secure enough claims to enable them to control both the election of the trustees and the selection of their counsel. These activities have forced many substantial firms into bankruptcy because of temporary financial stringency. ${ }^{74}$

While the collection agency is unhampered by professional restrictions in the matter of advertising and soliciting for business, it cannot represent its clients in court, since only attorneys can conduct litigation. The attorney, on the other hand, can avail himself of all legal process, but lacks the agency's

os Grocers and Merchants' Bureau v. Gray, supra note 11 (the collection agency had been organized under a statute permitting incorporation for the purpose of conducting commercial, mercantile, and protective agencies for the collection of debts and for the purposes usual and appropriate to the business of such agencies).

69 People v. California Protective Corp., supra note 63.

ro Buxton v. Lietz, 136 N. Y. Supp. 829 (MIun. Ct. 1912); affd, 139 N. Y. Supp. 46 (the collection agency was operated by an individual and not a corporation).

71 State v. Merchants Protective Ass'n., supra note 14.

i2 Mieisel v. Nat'l. Jewelers' Board of Trade, supra note 66. The court. said:

"The promissory notes required examination as to execution and the form of the signature, i.e., whether the maker was liable in an individual or a representative capacity, whether signed in a trade name as distinguished from an individual name, etc. Inquiry was necessary concerning the inception and delivery of the notes, whether for value or accommodation and as to any possible defense or counterclaim. Acting on this information the client would be advised whether to proceed. The next step would be the preparation of proof of claim. This is a legal instrument and the mere fact that it is on a printed form and might be filled out by a layman does not change its character, any more than the fact that confessions of judgment, bills of costs, affidavits of service and many simple forms of pleading on notes and for goods sold and delivered are frequently printed, changes their character. ..." Ibid. 25.

73 IIeisel v. Nat'l. Jewelers' Board of Trade, supra note 66.

74 Report of Committee on Unlawful Practice of the Law, 11 N. Y. CounTY L..A. Year Book, 162, 165 (1919); Gambrell, The Practice of Law by Trust Companies and Other Lay Interests (1929) GA. B. A. 222, 247. 
ready access to the public. Various arrangements for joining forces have been tried. The simplest of these apparently is for the collection agency to maintain its own legal department by employing attorneys on a salary basis. ${ }^{75}$ This should be regarded as illegal practice. It breaks down the attorney-client relationship, since all communications are effected by means of lay intermediaries. It forces the attorney to divide his allegiance between the agency and the creditor. In addition, the court is imposed upon because the lawyer appears as attorney of record for the creditor while his real client is the agency.

Another plan used by agencies when they are unable to collect without suit, is to transmit the claim to attorneys, who receive percentages of the fees recovered. One such agency charged its clients "a $10 \%$ fee on all claims before suit" and "a $20 \%$ fee ... where suit is brought." The claims were forwarded to attorneys accompanied by the following: "This claim is given to you on a $10 \%$ basis and if collected we are to receive one-half of $10 \%$ from you. .." One of these attorneys was held to have violated a statute forbidding lawyers to give a valuable consideration to anyone placing in his hands a demand for suit."

Still another arrangement is what practically amounts to a partnership agreement between an agency and an attorney, by which the former handles collections when no legal proceedings are required and the latter conducts any necessary litigation. One court has regarded such an arrangement as constituting an elusive attempt by a corporation to practice law under the guise of its attorney associate, and held that the contract between the agency and its customer was void as against public policy. Since the obligation was joint, that is, payments were to be made to the plaintiff corporation and the plaintiff attorney jointly, neither plaintiff, irrespective of the arrangement for the division of fees between them, could recover their fees from the customer. ${ }^{77}$

is The converse of this scheme is the operation of a collection agency by the attorney, sometimes under an assumed name. For practices in this connection which have been held unethical, see In re Rothschild, $140 \mathrm{App}$. Div. 583, 125 N. Y. Supp. 629 (1910); Matter of Thayer, 198 App. Div. 311,190 N. Y. Supp. 392 (1921); Matter of Schwarz, 195 App. Div. "194, 186 N. Y. Supp. 535 (1921), aff'd, 231 N. Y. 642, 132 N. E. 921 (1921). In re Swihart, $42 \mathrm{~S}$. D. 628, 177 N. W. 364 (1920); In re Dows, $168 \mathrm{Minn}$. 6, 209 N. W. 627 (1926).

${ }^{76}$ Matter of Newman, 172 App. Div. 173, 158 N. Y. Supp. 375 (1016) (N. Y. Penal Law \& 274). See A. B. A. Supplemental Canons of Professional Ethics, Nos. 34 and 35 dealing with division of fees and luy intermediaries, and criticism of these canons by the Chicago Bar Ass'n. 17 A. B. A. Jour. 418 (1931).

77 Midland Credit Adjustment Co. v. Donnelley, 219 Ill. App. 271 (1920); cf. Browne v. Phelps, 211 Mass. 376, 97 N. E. 762 (1912); McIver v. Clarke, 69 Miss. 408,10 So. 581 (1891).

The association of lawyers and constables as partners in a collection 
As yet we have no satisfactory statement of the proper relationship between attorneys and collection agencies. ${ }^{38}$ The latter flourish, and some of the former, having little knowledge of the propriety of their conduct, make all sorts of arrangements with them. ${ }^{79}$ If the lay agency is to be permitted to transmit claims to attorneys, then some legitimate means should be found to

agency has been condemned. Grievance Committee v. Clifford, 97 Atl. 975 (R. I. 1916).

is The Committee on Professional Ethics of the N. Y. County Bar Ass'n. had declared the following practices improper:

"The division with the lay agency of fees for the lawyer's services.

The guarantee by the agency of the lawyer's honesty or efficiency.

The solicitation by the agency of the employment of its attorney.

Compensation of the agency by the lawyer for its solicitation of claims for him.

Furnishing such compensation in disguise by the lawyer charging its patrons less than his other clients for similar services, in order that it may be paid.

A partnership between the lawyer and the agency involving the rendition of legal services by him.

The receipt by the lawyer of compensation from the agency as its employee, for his professional services to its patrons.

The offer of the lawyer's services by the agency to its patrons.

The practice of law by the agency.

The use of an officer of the agency as a cloak to enable the lawyer to do what he could not otherwise properly do.

The habitual recommendation of the lawyer by the agency so as to amount to systematic solicitation for him." Questrons REsPECTING Proper Professional Conduct (1929) Question 260. Cf. Question 51.

Some of the opinions of the committee seem inconsistent, for example: $A$, a collection agency, forwards a claim to $B$, an attorney on a $7 \%$ net basis. $B$ collects and remits to $A$ less the $7 \%$. A remits to its client less 10\%. The client knows that the claim was collected by an attorney who received part of the $10 \%$. The committee considered this arrangement improper. Question 125.

Question 220 is as follows: "It is the general practice for attorneys to receive commercial collections from collection agencies, and to the account so received, there is usually attached a schedule of rates as follows: 'Fees net to attorney, $10 \%$ on the first $\$ 300$, etc.' Undoubtedly the forwarding agency retains from this account remitted to it by the attorney an additional fee." This arrangement was considered proper if the attorney remembered that the creditor and not the agency was his client. Cf. Questions 260,51 .

What if the lawyer performs the same memory feat in Question 125? What is the objective test?

${ }_{79}$ "Now in Virginia, such a decision would come as a distinct shock, for we suppose it is a daily occurrence for lawyers of the highest standing to receive claims from collection agencies and divide fees. The idea that this was unprofessional has never occurred to them." 2 VA. L. REG. (N. S.) 865, 868 (1917). The Chicago Bar Association has taken a step toward removing this ignorance by the dissemination of pamphlets among the members of the bar. See Report of Committee on Unlawful Practice, IrL. B. A. REP. (1927) 261, 262; Chicago Bar Association Code Defining Unzauthorized Practice of Law, 6 LoS ANGeres B. A. BuLr. 159 (1931). 
compensate it for its previous efforts to enforce payment.

Disbarred and Suspended Attorneys Courts have always been very hesitant to suspend or disbar attorneys because of the severity of the punishment imposed. ${ }^{80}$ The person subjected to either of these penalties must therefore have shown himself to be unfit to be entrusted with the affairs of others either because of insufficient legal knowledge or because of some character imperfection. Since reinstatements are rare ${ }^{81}$ the disbarred attorney has little hope of reentering the profession. But the attorney whose license has merely been suspended will at some future date be reinvested with all the rights and privileges of the profession, provided that he shall have in the interim fully complied with the terms of the suspension order. ${ }^{82}$ Since he hopes to renew practice at some future date, he may be expected to attempt to retain his clientele, perhaps by resorting to improper methods. He is further confronted with the problem of earning a livelihood during his period of penance. Despite these temptations to obtain the emoluments of the profession by means of some subterfuge or other, he must so conduct himself that there shall not be the slightest ground for suspicion on the part of the members of the bar or the public that he is practicing law. ${ }^{83}$ The reasons are obvious and grounded in public policy. ${ }^{84}$

The suspended attorney must thus carefully refrain from holding himself out to the public as being qualified to act as an attorney. He should not encourage people to see him on legal matters or give them legal advice. He should remove his shingle and discontinue using his legal stationery. He should not permit his name to be published as an attorney in the city or telephone directories. These are affirmative duties, and courts refuse to

80 See Bradley v. Fisher, 13 Wall. 335, 354 (U. S. 1871).

81 Reinstatement proceedings have been regarded as applications for admission to the bar, and not as applications to vacate the order of disbarment. Danford v. Superior Court, 49 Cal. App. 303, 193 Pac. 272 (1920).

s2 It has been held that a suspended attorney could claim the benefit of a statute exempting from attachment the "tools, apparatus, and books," belonging to members of the legal profession. McBrayer v. Cravens, 265 S. W. 694 (Tex. 1924). Note (1925) 23 Mich. L. Rev. 530.

But it is generally held that where an appearance in court is necessary to the fulfillment of the duties of a public office (such as that of prosecutor) suspension or disbarment is a disqualification for the office. Danforth v. Egan, 23 S. D. 43, 119 N. W. 1021 (1909), Note (1920) 29 YAlE L. J. 796. But $c f$. State ex rel. McAllister, Atty. Gen. v. Sanderson, 280 Mo. 258,217 S. W. 60 (1919). But not where the incumbent is not required to by a lawyer. State v. Swan, 60 Kan. 461, 56 Pac. 750 (1899); Strate v. Peck, 88 Conn. 447, 91 Atl. 274 (1914).

83 In re Lizotte, 32 R. I. 386, 79 Atl. 960, 35 L. R. A. (N. S.) 794 (1011); see In re Dangler, 205 App. Div. 94, 199 N. Y. Supp. 306 (1923).

84 See Cobb v. Judge of the Superior Court, 43 Mich. 289, 291, 5 N. W. $309,310(1880)$. 
credit pleas that they have been violated through inadvertency.

One obvious method of evading the suspension order is to secure "employment with another attorney. Another method is to continue clandestinely office practice and to employ another lawyer to appear as attorney of record, while the suspended lawyer does all or most of the work involved in preparing cases for trial, including investigating and interviewing witnesses and preparing pleadings and appeal briefs. ${ }^{s 0}$ Disbarred attorneys have also resorted to these expedients.s:

Since disbarment and suspension merely deprive attorneys of their franchise to practice law, they may, like anyone who has attained majority, appear in person to assert or protect their own rights. ${ }^{\text {s8 }}$ This right offers a convenient loophole to the disbarred or suspended attorney who wishes to practice law. By adopting the subterfuge of having his clients assign their claims to him for the purpose of prosecution, he is enabled to appear in court, ostensibly merely protecting his own interests.

In 1923, the California legislature attempted to curb this practice by passing an act which forbids a disbarred attorney to appear in his own behalf in the prosecution of a claim assigned to him after entry of judgment of disbarment. The Court of Appeals for the First District held this act to be in contravention of the constitutional right to "acquire and protect property," since one acts as an attorney only when he acts for some one else while here the defendant was merely acting for himself.: In a later case arising in another district the disbarred attorney admitted that the claim had been assigned to him for collection for the benefit of the assignor. The court refused to allow him to prosecute the claim and declared the statute to be a proper exercise of the power of the legislature.

85 In re Lizotte, supra note 83 , State ex rel. Patton, Atty. Gen. v. Marron, 22 N. MI. 632, 167 Pac. 9 (1917); State v. Richardson, 125 La. 644, 51 So. 673 (1910) ; People v. Humbert, 282 Pac. 263 (1929) (disbarred attorney).

86 These activities are punishable by disbarment. State v. Fisher, 103 Neb. 736, 174 N. W. 320 (1919); Note (1920) 29 Yale L. J. 350.

si See Miatter of Quitman, 152 App. Div. 865, 137 N. Y. Supp. 1069 (1912).

$A$, an attorney, who was handling a case for $C$ on a contingent fee, was disbarred. $A$ arranged with $B$, another attorney, to handle the case. $B$ agreed to divide his fee with $A$. Later the client attempted to substitute a new attorney. Both $A$ and $B$, were held to have forfeited the attorneys' lien as the arrangement was regarded as violative of a statute forbidding attorneys to split fees except with other attorneys. Dudar v. Mrilef Realty Corp., 227 App. Div. 279, 237 N. Y. Supp. 499 (1929); Note (1930) 78 U. of PA. L. REv. 1021.

S\& THORNTON, loc cit. supra note 20.

sa O'Connell v. Judnich, 235 Pac. 664 (Cal. App. Dec. 1925); Note (1926) 30 LaW Notes 23. 
"It is common knowledge that collection agencies pursue the policy of taking assignments of claims for the purpose of bringing action, and that the only interest the assignee has in the subject matter is a percentage thereof as his own compensation for doing those things ordinarily performed by an attorney. . . . In substance then, the only interest the assignee or plaintiff could have would be the fruit of doing that which he is disbarred from doing, to wit, practicing his profession." 80

Ambulance Chasing Ambulance chasing is a term applied to the procurement of retainers in negligence cases by means of personal solicitation or more generally, by the employment of lay agents, usually called runners. ${ }^{01}$ It is also a device which enables the layman to practice law illegally, sharing in the emoluments of the profession without being subject to its duties and obligntions. ${ }^{92}$ In recent investigations instituted by bar associations under the supervision of the courts ${ }^{23}$ it was found that many runners, not satisfied with being mere adjuncts to law offices, set up shop on their own account, soliciting claimants with printed contracts for retainers on a fifty per cent. contingent fee basis, with the name of the attorney left blank. In securing these r'etainers they often claimed to represent a well-known firm of attorneys, which in fact had in no way authorized such representation. Some of these independent runners formed connections. with members of the bar whose names they used in bringing suit in cases which they were unable to settle without litigation. The lawyers expected to, and in fact usually did, take very little part in the proceedings, receiving a small compensation either in the form of a salary or a commission. At the same time that the attorney signed the writ he gave the runner an order for the discontinuance of the case. Complete control of the case was thus in the hands of the runner, who, rather than the claimant, was the client of the attorney. At any rate the latter clearly had prostituted his office. The runner usually tried to settle cases, because in the event of trial, he would have to split his fees with an attorney. Influenced by this fact, he often settled meritorious causes for much less than they were worth. Failing to make a settlement he would "peddle" the case around and sell it to the attorney paying the highest price. Thus ambulance chasing

90 Koepple v. Morrison, 257 Pac. 590, 591 (Cal. App. Dec. 1927); Noto (1927) 31 LAW NOTES 124.

91 See in re Association of the Bar of the City of New York, 222 App. Div. 580, 227 N. Y. Supp. 1 (1928).

82 See Alpers v. Hunt, 86 Cal. 78, 81, 24 Pac. 846, 849, 9 L. R. A. 483, 486 (1890) ; State v. Kiefer, 197 Wis. 524, 529, 222 N. W. 795, 796 (1920).

${ }^{23}$ See People ex rel. Karlin v. Culkin, .248 N. Y. 465,162 N. E. 487 (1928) ; Rubin v. State, 194 Wis. 207, 216 N. W. 513 (1927); Petition of Childs, 26 Ohio Law Rep. 355, 515 (1928). Matter of Brooklyn Bar Ass'n, 223 App. Div. 149, 227 N. Y. Supp. 666 (1928). 
appears as one of the most objectionable forms of illegal practice. ${ }^{93}$

Insurance Companies Many insurance contracts incidentally provide that the company shall defend the insured, in his name and on his behalf, from suits for damages.95 The latter appears to be an agreement by a corporation to furnish attorneys to third parties, a service which in other connections has been held to constitute illegal practice of the law. Insurance companies justify this procedure by the argument that the attorneys are protecting the interests of the company as well as those of the insured since the company must pay any judgment within the limits of the policy. They make a practice of defending in the name of the insured because juries, motivated by sympathy, might be tempted to disregard the real issues and grant exorbitant verdicts if the insurance company were the defendant. Opposed to this argument is the fact that the company's attorney, whether he be a salaried employee or specially engaged for the case, is often forced to represent conflicting interests. For example, in one instance, the insurance company denied that the claim arising out of an accident was covered by the policy, but nevertheless undertook to defend the suit with the understanding that it did not thereby assume any liability. Its attorney then advised the insured to settle. When, after the settlement, the insured brought an action on the policy the same attorney set up against the insured, his former client, a provision of the policy that the company should not be liable except for the amount paid on a judgment obtained after the trial of an action..$^{96}$

Courts will probably uphold the contention of insurance companies that they are merely protecting their own interests when they furnish the insured with counsel. ${ }^{97}$ This argument, however, is untenable unless the company is required by the policy to pay the amount of the judgment. Some so-called insurance contracts are merely agreements for the rendition of legal

94 Shaw v. State Bar of California, 297 Pac. 532 (Cal. 1981); Smallberg v. State Bar of California, 297 Pac. 916 (Cal. 1931) ; Report of the Committee of Censors to the Law Ass'n. of Pliula., In re Contingent Fee Accident Leg. p. 6; Nationwide War on "Ambulance Chascis" (1928) 14 A. B. A. Jour 561, 562; Aarons, The Practice of Law by Non-Lauycrs (1929) 14 MLARQUETTE L. ReV. 1.

as See Hutebner, Property Insurance (1922) 422.

${ }^{36}$ See Practice of Law by Insurance Companics, 13 BeNCH AND BAR (N. S.) 106, 107 (1918) ; Bristol supra note 7, at 593 et. scq.

${ }^{97}$ It has been held that a corporation formed for the purpose of guaranteeing bonds and mortgages might properly employ attorneys to foreclose mortgages which they had guaranteed, since it was a proper party to such litigation. In re Kelsey, 186 App. Div. 95, 173 N. Y. Supp. 860 (1919).

Statutes in several states forbidding lay practice of lav provide that they shall not apply to insurance companies. II.tSS., IInNN., N. C., R. I., supra note 12. But see note 41 , supra. 
services. For example, one type of policy offers to defend malpractice suits brought against physicians. The company agrees to pay court costs and to furnish attorneys but not to pay the amount of the judgment if any is returned against the physician. Some courts have held that such companies cannot operate without complying with the insurance laws. ${ }^{08}$ Such decisions, however, are not determinative of the question whether or not such companies are practicing law. ${ }^{90}$ Obviously, no license issued by the insurance commissioner of the state would of itself entitle the holder to engage in the practice of law. ${ }^{100}$ One court refused to permit such companies to operate within the state on the ground that the services offered were legal services and hence could not be performed by a corporation..$^{10 x}$ The mere presence or absence of a policy should not determine the legitimacy of the enterprise. For if this were the controlling feature, what would prevent a corporation from guaranteeing a minimum recovery in every suit for breach of contract, paying the minimum amount in advance under a guaranty which permits them to furnish lawyers and to prosecute such causes of action? What would prevent corporations from furnishing attorneys for the prosecution of negligence cases by the simple expedient of selling "policies" guarnnteeing minimum recoveries? 102 In brief, the "policy" could be used as a wedge for entering almost every field of litigation.

Notaries and Accountants In many foreign countries the notary is a specially trained official, a sort of quasi-lawyer, who is authorized to draft legal instruments and give advice concerning them. In this country notaries, whose chief function is to acknowledge instruments, are not permitted to practice law unless they also happen to be licensed attorneys. In cities having large foreign populations many notaries have practiced law by pretending to credulous and ignorant people that they are competent to give legal advice and to act as draftsmen. Some notaries have been punished for this illegal law practice, ${ }^{103}$ but convictions are difficult to obtain because the victims usually speak

88 Physicians' Defènse Co. v. O'Brien, 100 Minn. 490, 111 N. W. 396 (1907); Physicians' Defense Co. v. Cooper, 199 Fed. 576, 47 L. R. A. (N. S.) 290 (C. C. A. 9th 1912). Contra: Vredenburgh v. Physicians' Dafense Co., 126 Ill. App. 509 (1906). 1 CooleY, INSURANCE (2d ed., 1927) 124; 6 Ibid. 5621.

9o See Allin v. Motorist's Alliance, 29 S. W. (2d) 19, 23 (Ky. App. 1930). 100 See Towmsend v. State Bar of Calif., 291 Pac. 837, 838 (Cal. 1930).

101 State ex rel. Physicians' Defense Co. v. Laylin, 73 Ohio St. 90, 76 N. E. 567 (1905).

102 Report of Committee on Unlawful Practice of the Law, 11 YaAR BOoK, N. Y. CoUNTY L. Ass'N. (1919) 162, 169.

${ }_{103}$ People v. Alfani, supra note 36; Report of Committeo on Unlanful Practice of the Law, 8 YEAR BooK, N. Y. CounTY L. Ass'N. (1916) 173, 183. 
English poorly and are too ignorant to appeal to the proper authorities. In some instances the notary serves as a soliciting agent for a law office. ${ }^{104}$

The Federal Tax Department has apparently authorized accountants to fill out and prepare income tax returns for others. In the ordinary case probably little harm results. But in many instances knowledge is required of such intricate matters as the law of domicile, or the effect on taxation of increase and decrease of corporate stock, of merger, consolidation, incorporation, partnership and dissolution. Statutes must be interpreted, and cases must be found and construed. In this work a knowledge of the fundamentals of law is necessary. The superficial business law courses usually taken by accountants are woefully inadequate. The normal function of the accountant is limited to the examination of books and the preparation of schedules, and he is neither authorized nor usually competent to advise clients on questions of law arising out of the administration of the tax statutes. ${ }^{103}$

\section{III}

It is evident that many laymen and lay agencies are operating in the field which is and always should be limited to lawyers. On the other hand we cannot return to the time when theology and law were the only learned professions. Laymen have rightfully entered and cannot be evicted from part of the lawyers' ancient preserves. Ill-advised and hasty attempts at retaliatory, prohibitive, and permissive legislation will only add to the confusion.

There is a narrow neutral zone in which both lawyers and laymen can operate. Failure to admit that this zone exists merely encourages the latter to "bootleg" all types of legal services in the zone and beyond it. ${ }^{100}$ But the layman "practicing" within the zone should be subject to regulation just as is the lawyer. Some types of practice should be permitted only when incidental to a regular business. Others should be permitted to laymen only through the agency of independent attorneys. When direct individual service is given licenses should be required, and granted only on proof of skill.

\footnotetext{
104 See Matter of Treadwell, 175 App. Div. 833, 162 N. Y. Supp. 551 (1916).

105 Report of Committee on Recommendations of the Confcrence of Bar Associations-Appendix A, 44 N. Y. S. B. A. RER. (1921) 287, 361; Rcport of Committee on Unlawful Practice of the Law, 14 YaAR Book, N. Y. CoUnTY L. Ass'N (1922) 172, 183.

In some instances accountants have attempted to enter illegally the general field of the practice of law. Re Morse, supra note 3.

${ }_{100}$ See Ashley, The Unauthorized Practice of Law, 16 A. B. A. Jour. 558 (1930).
} 
For the delineation of the neutral zone further investigation into existing fact situations is first necessary. Many of the current assumptions upon which arguments are based are pure guess-work. To what extent are laymen and lay agencies giving legal advice and drafting legal instruments? How many lay agencies hire attorneys to furnish such services for customers? To what extent is litigation actually employed in the collection of claims? What types of relationships exist between laymen and lawyers and to what extent are they illegal or violative of the rules of professional conduct? How successfully from the viewpoint of the client do the activities of competing lawyers and laymen operate? These are questions, typical of many, which are worthy of careful research.

In the meantime, even under present limitations of knowledge, some constructive measures can be taken. It is possible to elim. inate much illegal activity by authority of existing statutes. The offender can be subjected to fine or imprisonment. Offending corporations can be deprived of their charters. In two states injunctions against lay practice may be granted at the suit of attorneys. ${ }^{107}$ More effective action could be taken if there were a clear and adequate definition of the practice of law. Definitions, even in the newer statutes, are usually in general terms and are not very helpful as to particular matters until there has been a clear expression of judicial opinion. ${ }^{105}$

The above statements relate to remedies by the enforcement of statutes. Much more can probably be accomplished by less drastic means. Misunderstanding concerning the status of fiducinry work by corporations should be removed. It has been suggested that if laymen are to be permitted to compete with attorneys for work of a fiduciary nature they should be subjected to the same or similar ethical restrictions, and be held to the same degree of responsibility, as are lawyers. The right of corporations to act as trustees and executors is now well established in most states. It has been contended that that right ought not to be accompanied by the privilege of advertising their abilities in these capacities since lawyers are not allowed a like privilege. ${ }^{\text {1no }}$ Mere business is not being sought, but the establishment of a relationship involving trust and confidence. These organizations do not merely praise the corporation as a fiduciary, but also,

107 Ohio and N. C. See notes 60,61, supra; Goodman v. Western Bank \& Trust Co., 3 Ohio Bar Rep. 609 (1931); N. C. Public Laws 1931, c. 157 $\S \S 1,2$.

108 Prosecuting attorneys have hesitated to prosecute. Beardsley, Lay Encroachments (1931) 36 Comm. L. J. 275.

${ }^{109}$ Activities of Banks and Trust Companies, 16 Mass. L. Q. 12 et. seq. (Jan. 1931); 9 Ibid. 35 (May 1924); 10 Ibid. 11 (Feb. 1925). Slater, Corporate Fiduciaries and Legal Ethics (1931) 17 A. B. A. Joun. 441. 
sometimes in scare-head type, disparage the individual trustee by over-emphasis on losses from inefficiency and fraud. At best this presents a one-sided picture of a clearly debatable matter. As has been shown above, the interests of the testator and his beneficiaries will often be best served by an individual trustee acting either alone or in concert with a corporate fiduciary. At present there is no agency presenting to the public this side of the picture. The individual attorney cannot do this, not only because he is expressly forbidden to advertise by the code of professional ethics, but also because his financial resources are limited. It has therefore been suggested that this burden be undertaken by the bar associations. ${ }^{110}$

The ethical considerations underlying the rules forbidding an attorney to advertise or to solicit business are briefly as follows. Since he is an officer of the court, an aide in the administration of justice, advertising his readiness to do justice would be undignified and incongruous. It would also tend to stir up litigation based on frivolous and fraudulent claims unfairly burdensome to defendants and tending to glut court calendars. The lawyer has no wares to offer like a shop-keeper, his stock in trade consisting only of his shill and trustworthiness. None of these objections would seen to be valid against advertising in the general interests of the profession by bar associations. A wealmess of this plan is that bar associations are at present financially unprepared to compete with the expensive advertising campaigns carried on by corporate fiduciaries. It may nevertheless be possible to secure effective publicity by the publication of short and dignified articles in leading periodicals and in local magazines throughout the country. An alternative to advertising by bar associations is the enactment of statutes forbidding corporations to advertise themselves as fiduciaries. Such a statute has been proposed in Massachusetts. ${ }^{111}$ A practical objection to the plan is the virtual impossibility of securing such legislation over the powerful lobbying influences of the corporate fiduciaries.

The conflict of interests between lawyers and laymen in regard to law practice may largely be removed by coöperation, conferences and mutual agreements conscientiously observed. Farseeing and progressive corporation officials realize the importance of retaining the good will of attorneys. The latter have much to gain by friendly contact with corporations. In neither case is the attitude altruistic, because both derive lucrative business from the relationship. A case in point is coöperation between bar associations and trust company officials. Some of the

${ }_{110}$ Collective Advertising of the Bar by Bar Associations, 15 MInss. L. Q. 61 (May 1930).

111 House Bill No. 499, 16 MLASs. L. Q. 43 (Jan., 1931); see note 109, supra. 
latter concede that corporate practice of the law is fundamentally unsound and subversive of the best interests of the public, but they contend that a clear delimitation of the prohibited field is essential. ${ }^{112}$ Steps in this direction have recently been taken through the efforts of the Trust Companies Division of the American Bankers Association in coöperation with local bar associations. The result in one instance which may be taken as typical was the adoption of codes, specially dealing with the problem, by the Ohio Bankers Association and the Ohio Bar Association. ${ }^{113}$ These are worthy of quotation in full: .

\section{Code for Banks and Trust Companies}

"First. A bank should not advertise that it maintains a Legal Dopartment.

"Second. A bank should not through an officer, employee, or other porson employed for that service, draw wills except in cases in which tho will-maker is also represented by a lawyer employed by him. A bank should not employ solicitors to persuade persons to have their wills drawn by an officer or an employee of a bank.

"Third. A bank should endeavor to cause the client of its trust dopartment to consult with legal counsel of his own in connection with any matter of a fiduciary nature.

"Fourth. A bank should not prepare any legal instrument in any transaction to which it is not a party.

"Fifth. A bank should not prepare forms for nor minutes of corporato proceedings in which it is not interested. A bank should not draw leases, contracts, deeds, mortgages and other legal documents in matters in which it has no interest unless it performs some act or function in connection therewith.

"Sixth. No bank or trust company or trust officer shall be paid for or receive compensation for services as counsel to any trust estate for which such bank is trustee. Such services as counsel are taken to includo appearances in court, the preparation of instruments by the trust officer or giving of advice upon legal matters by said trust officer.

"Seventh. Where a bank or trust company charges and collects from a mortgage loan borrower an attorney fee for examination of title or abstract in connection with a mortgage loan, no part of such attornoy feo should be retained by the bank or trust company.

"Eighth. Where reports by titles or abstracts are furnished to a bank or trust company by an abstract or title company in connection with a real estate mortgage loan, the charge made to the borrower for such sorvico rendered by said abstract or title company should not be designated as attorney fees or trust charges."

112 Griswold, Some Aspects of the Relationship between T'nust Companies and the Legal Profession (1929), 48 Trust Cos. 409, 753; $A$ Letter from a Trust Officer, ibid. 621.

113 Ibid. 914; The Jamestown (N. Y.) Code, 47 ibid. 779; The Buffalo Code, 51 ibid. 173 (1930); Missouri, ibid. 175; The Baltimore Code, 6 Los angeles Bar Bull. 309 (1931); New Orleans Bar Bull. See Griswold, Fostering Cooperation with Lawyers (1930), 51 TrusT Cos. 609; Bradshaw, Vindication of Lawyer-Trust Company Cooperation in Wasitington, ibid. 159 . 
Code for Lawyers

"First. The members of the Bar, recognizing the legal capacity of the trust departments of banks to administer estates, and conduct trusteeships, should, in all cases where a bank or trust company is named in a will as executor or trustee, or is named in some fiduciary agreement as trustee, consult with some representative of the Trust Department of such bank or trust company with reference to the terms of the will, or other instruments, so far as it creates trusteeships or executorships.

"Second. When a client indicates to a member of the Bar his desire or intention to name a bank or trust company as executor or trustee under his will, the member of the Bar should not discourage or influence the client against the use of a bank or trust company in acting in such capacity."

The success of the method of coöperation and agreement, when applied to all types of lay agencies, depends largely upon the extent to which they have been organized into representative, responsible associations which stimulate in their members a high consciousness of the ethical obligations of their callings.

Lawyers are already organized into associations provided with general codes of conduct and influenced by professional traditions. Nevertheless, some of them, including influential members of the bar, ${ }^{114}$ are aiding laymen to practice law illegally, and are thus themselves guilty of unprofessional conduct. ${ }^{115}$ In some instances these lawyers are in complete ignorance of the unprofessional character of their acts. In others they are well informed but salve their consciences by arguing that they cannot give up such lucrative business until others do so. This breakdown in professional morale, especially among the leaders of the bar, has had an unfortunate effect upon the rank and file of attorneys, many of whom have resorted to such déclassé practices as ambulance chasing in order to procure business. "If gold rust, what shall iron do?" "When unprofessional methods of obtaining business are mentioned, trust company lawyers mean the bankruptcy ring, the bankruptcy lawyer means the ambulance chaser, the ambulance chaser points at the lawyer whose retainers are sent him by the trust company." 116 While a large number of attorneys have been disciplined because of unethical bankruptcy practices, advertising or ambulance chasing, the instances of disciplinary proceedings for illegal practice of the law are comparatively rare. All the canons of professional ethics should be applied to all members of the bar. Otherwise the legal fraternity should frankly admit that these canons are out-

114 See Roberts, The Unlawful Practice of Law (1931), 24 Lawren \& BANKER 80.

115 Supra note 53; In re Otterness, supra note 32; Miatter of Pace, supra note 45; In re Gill, 104 Wash. 160, 176 Pac. 11 (1918). See Buxton r. Lietz, supra note 70, at 832.

116 Jackson, Function of the Trust. Company in the Field of the Lan (1929) 52 N. Y. S. B. A. REP. 142, 150.

\section{0}


worn and obsolete. There is no "conceivable difference between employing John Doe, your own clerk, as a runner for business and employing 'John Doe, Inc., Collection Agency' "117 or Bank or' Trust Company, for the same purpose.

If the bar expects any coöperation from the public in the elimination of the illegal practice of the law it must impartially discipline its delinquent members, raise the standards for admission to the bar and limit the number of those admitted to the actual needs of society. The leaders of the bar are already conscious of the short-comings of their colleagues in the profession and of the necessity for radical improvements in the administration of justice. ${ }^{118}$ From the point of view of lay education, however, perhaps too much emphasis has been placed on these features of the present situation. The difficulties of the problem not attributable to the bar but inherent in democratic government, in which courts and the bar are essential elements, should also be stressed if the public judgment upon the status and importance of the professional practice of the law is to be well-balanced. ${ }^{119}$

117 CoHeN, The LAW: BUSiness OR Profession (1924) 227.

118 Improvement of the administration of justice has been suggested as a method of eliminating unauthorized practice of the law. See Shinn, How to Deal with the Unlawful Practice of Law (1931), 17 A. B. A. Jour. 98; Klein, Sell the Legal Profession (1927), 2 CALIF. S. B. Jour. 74. 119 See Manton, "Popularizing" the Law and "Legalizing" tho Nows (1931), 65 U. S. L. REv. 419. 